\section{Marine Geology}

Vol. 234, Issues 1-4 , 18 Dec. 2006, Pages 111-128

http://dx.doi.org/10.1016/j.margeo.2006.09.020

(c) 2006 Elsevier B.V. All rights reserved
Archimer, archive institutionnelle de l'Ifremer http://www.ifremer.fr/docelec/

\title{
Massive sand beds attributed to deposition by dense water cascades in the Bourcart canyon head, Gulf of Lions (northwestern Mediterranean Sea)
}

\author{
M. Gaudin ${ }^{a}{ }^{\star}$, S. Bernéb ${ }^{b}$ J.-M. Jouanneau ${ }^{a}$, A. Palanques ${ }^{c}$, P. Puig ${ }^{c}$, T. Mulder ${ }^{a}$, P. Cirac ${ }^{a}$, \\ M. Rabineau ${ }^{d}$ and P. Imbert ${ }^{\mathrm{e}}$
}

\author{
${ }^{a}$ DGO, UMR-5805 EPOC Université Bordeaux1 Av. des Facultés 33405 Talence, France \\ ${ }^{b}$ GM-LES IFREMER BP70 29280 Plouzané, France \\ ${ }^{\mathrm{c} I n s t i t u t ~ d e ~ C i e ̀ n c i e s ~ d e l ~ M a r ~(C S I C), ~ P a s s e i g ~ M a r i ́ t i m ~ d e ~ l a ~ B a r c e l o n e t a ~ 37-49, ~ B a r c e l o n a ~ 08003, ~}$ \\ Spain \\ dUMR6538 Domaines océaniques, IUEM, 29280 Plouzané, France \\ ${ }^{\mathrm{e}}$ TOTAL CST JF, Avenue Larribau 64000 Pau France \\ *: Corresponding author : m.gaudin@epoc.u-bordeaux1.fr
}

\begin{abstract}
:
Nowadays, the Gulf of Lions continental shelf and slope are under the influence of dense water cascading, wind-induced bottom currents and the geostrophic Northern Current. In order to characterize sedimentary activity at the shelf break, several interface and piston cores were taken in the Bourcart canyon head and a current meter equipped with temperature, conductivity, pressure and turbidity sensors was moored during the 2003-2004 winter season. Even if the canyon is not connected directly to continental sources since Last Glacial Maximum, detailed grain size, X-ray and sediment facies analysis of interface cores show that down to $350 \mathrm{~m}$ water depth, the canyon head is blanketed by up to $1.5 \mathrm{~m}$ of structureless muddy medium-grained sand. 210Pbexc activity measurements demonstrate present day sedimentary activity of the canyon head. Time series of currents with peak velocity reaching $0.37 \mathrm{~m} / \mathrm{s}$, suspended sediment concentration and temperature indicate that dense water cascading is the main process allowing the reworking, transport and accumulation of sand within the canyon head, even though winter 2003-2004 was characterized by low cascading events compared to other years. These sand beds, called "cascadite" constitute a new type of deposit that differs from other typical slope deposits (turbidites, hyperpycnites, contourites) in terms of flow duration and sedimentological characteristics. They are similar to shallow water contourites. They might be time-equivalent to the recent turbidites described throughout the deep western Gulf of Lions basin.
\end{abstract}

Keywords: submarine canyon; cascading; sand deposits; ${ }^{210} \mathrm{~Pb}_{\text {exc }}$ activity 


\section{Introduction}

Submarine canyons have been considered for a long time to be the main transfer zone for continental-derived sediment to reach the deep sea (Shepard and Dill, 1966). Numerous studies documented the transit of gravity driven flows down, for instance in the Monterey, Capbreton, Kaikoura or Zaire canyons (Garfield et al., 1994; Khripounoff et al., 2003; Lewis and Barnes, 1999; Mulder et al., 2001; Paull et al., 2003). However, these canyons are either directly connected to a river system or located close to the shoreline and therefore under the influence of inner shelf and/or fluvial dynamics (Liu and Lin, 2004; Mullenbach and Nittrouer, 2000; Mullenbach et al., 2004; Puig et al., 2003; Segall et al., 1989; Shanmugam, 2003; Shepard and Marshall, 1973; Snyder and Carson, 1986; Thorbjarnarson et al., 1986; Xu et al., 2002).

In other cases, however, present day sea-level conditions prevent direct river connection with submarine canyons. Therefore, such canyons are presumed to be inactive. However, in such environments, several studies documented the transport of sand and fine-grained material at the shelf edge and into submarine canyons by hydrodynamic or climatic forcing (Durrieu de Madron et al., 2005; Frignani et al., 2002; Ivanov et al., 2004; Kenyon, 1986).

In this study, a detailed investigation of the Bourcart canyon (also known as Aude Canyon) characterizes the wide-spread blanketing of the canyon head with a recent massive sand bed that formed presumably during episodes of intense shelf water cascading.

\section{Regional settings}

\subsection{The outer shelf}

The Gulf of Lions constitutes the north-western part of the Mediterranean Sea (Fig. 1). The continental shelf reaches up to $70 \mathrm{~km}$ in width. This rather unusual width in the Mediterranean Sea is explained by intense progradation during Plio-Quaternary under the influence of the large amount of sediment supplied by the Rhône (Lofi et al., 2003). The outer shelf morphology results from the stacking of prograding wedges (Aloïsi, 1986; Rabineau, 2001) deposited during “forced regressions" (Posamentier et al., 1992). The most recent wedge consists of lowstand sandy shoreface deposits that settled between $80 \mathrm{~m}$ and $120 \mathrm{~m}$ water depth, and of correlative offshore muds beyond $120 \mathrm{~m}$. The transition between the 2 facies is marked by a brink point in the sea-floor morphology reaching up to $25 \mathrm{~m}$ (Berné et al., 2004; Berné et al., 2002). The sea-floor roughness is attributed to subaerial erosion during 
the last glacial maximum, together with subsequent marine erosion during the transgressive phase. The transgressive deposits were subsequently reworked into dunes and sand ridges (Berné et al., 1998; Bassetti et al., this volume)

\subsection{The Bourcart canyon}

The shelf break is dissected by several submarine canyons that were mapped using swathbathymetry (Berné and Loubrieu, 1999) (Fig. 1).

The Bourcart canyon is located in the widest part of the shelf, $70 \mathrm{~km}$ off the southern coast of France. The canyon is almost connected, to the West, with shoreface sands that formed during the Last Glacial Maximum turnaround (Jouët et al., this volume, and Fig. 1). The study area (10 km x $20 \mathrm{~km}$, Fig. 2) corresponds to the head of the canyon, which consists of a main canyon, about $4 \mathrm{~km}$ wide and up to $400 \mathrm{~m}$ deep, partly filled by up to $300 \mathrm{~m}$ by sea-level fall and Last Glacial Maximum derived sediments (Fig. 3). This infill is incised by a meandering axial incision that formed during Last Glacial Maximum (Fig. 3), when the canyon was directly linked to a fluvial system (Baztan et al., 2005). The head of the canyon is topped, to the NW, by a 20 m-high relief made of cemented sands that are interpreted as beach rocks formed around $21 \mathrm{cal}$ ka BP (Jouët, this volume). The erosion of the axial incision by hyperpycnal and turbidity flows generated small scale failures that evolved in retrogressive slumps (Baztan et al., 2005). The sea-level rise induced the disconnection of the river from the head of the canyon ending direct fluvial sediment supplies.

\section{Hydrodynamic framework}

\subsection{The Northern Current}

The Gulf of Lions shelf break and continental slope are under the influence of the "LiguroProvencal" current or "Northern Current" (NC). The NC enters the Gulf of Lions on its eastern side and flows along the shelf break in a counter clockwise direction (Millot, 1991). Its velocity is maximum near the surface $(\sim 0.5 \mathrm{~m} / \mathrm{s})$ and decreases nearly linearly with depth to a few cm/s at several hundred meters depth (Lapouyade and Durrieu De Madron, 2001). However, its magnitude and direction can be modified by seasonal stratification and wind effects. In such cases, currents velocities up to $0.5 \mathrm{~m} / \mathrm{s}$ were recorded in the water column at depth $\sim 200 \mathrm{~m}$, and clockwise inertial currents can be formed on the shelf along the $100 \mathrm{~m}$ isobath with lower current velocities (0.1-0.2 m/s) (Petrenko, 2003). The interaction between 
the NC and the complex morphology of the shelf break produces deviations of the bottom current generating up-canyon, down-canyon or oscillating currents within the canyon particularly in the Grand Rhône (Durrieu de Madron, 1992) , Lacaze Duthiers canyons (Frignani et al., 2002)or Blanes canyon (Ardhuin et al., 1999).

\subsection{Meteorological forcing}

Wave and wind regime constitute a driving force of local circulation in the northwestern Mediterranean Sea. Northern (Mistral) and northwestern (Tramontane) winds are known to generate classical oceanographic features such as up and downwelling currents (Millot, 1990) or inertial oscillations (Petrenko, 2003). Recent studies demonstrate the impact of exceptional events such as storms or intense period of cold and dry winds on the Gulf of Lions local hydrodynamic. The strong winds cool the surface water that become denser than the surrounding waters and sink. The cold waters transit across the shelf and are transferred deeper through submarine canyons until they reach their buoyancy equilibrium (Durrieu de Madron et al., 2005; Ivanov et al., 2004). This process called shelf water cascading mainly occurs during winter time.

Another process contributing to increase current velocities in submarine canyon heads is the accumulation of water along the SW coastline of the Gulf of Lions during easterly storms. During the stratified season, despite a relatively light density, the load of water along the coastline induces downwelling and water escape in the SW corner of the Gulf of Lions (Palanques et al., this volume). However, according to these authors, this latest process restricted to the SW part, is combined with dense water cascading in winter and affects most of the Gulf of Lions submarine canyons usually between January-February and April.

\section{Data and Methodology}

The bathymetric map of the Bourcart canyon head was acquired with an EM1000 multibeam echo sounder during the Calmar and Strataform cruises in 1999 and 2002, with R/V “L’Europe” and "Le Suroît” respectively. An interface core device was used to collect wellpreserved samples of the upper $1 \mathrm{~m}$ of sediments. All together, 15 interface cores and 2 piston cores were recovered with the R/V "Le Suroitt" during the Strataform and GMO2 cruises in 2002 (Fig. 2). Coring in deep submarine channels is difficult because of uncertainties in position of the impact of the coring system (Paull et al., 2005). In order to minimize uncertainties, a D-GPS positioning system was used together with a Dynamic Positioning 
system for maintaining the ship at the position of the targeted coring site. The position of the cores was strictly controlled using swath bathymetry and sub-bottom profiling. The offset between the D GPS antenna and the frame of the piston coring system being of $9 \mathrm{~m}$, and considering the relatively shallow water of the study area (between $110 \mathrm{~m}$ and $600 \mathrm{~m}$ ) the resulting accuracy in the positioning of cores is estimated at about $50 \mathrm{~m}$.

Physical parameters (gamma ray, density, porosity, and magnetic susceptibility) were measured using a "Geotek" core logger located at Ifremer. Sedimentological analyses were performed at Bordeaux 1 University using a Malvern master-sizer for laser grain size analysis, and the SCOPIX system (Migeon et al., 1999) for X-ray imaging.

In order to characterize the coarse and fine fraction contents in the sediments collected, a Q index is used.

$\mathrm{Q}=\mathrm{S} / \mathrm{C}$, where $\mathrm{S}=$ sediment fraction $>63 \mu \mathrm{m}$, and $\mathrm{C}=$ sediment fraction $<63 \mu \mathrm{m}$.

It must be noted that the $63 \mu \mathrm{m}$ corresponds for Facies 2 to 5 , to a boundary between 2 grainsize populations with modes around 5-7 $\mu \mathrm{m}$ and 200-300 $\mu \mathrm{m}$.

Radioisotopic measurements were made using a high resolution gamma spectrometer with a semi planar detector (Jouanneau et al., 2002). Counting of ${ }^{210} \mathrm{~Pb}$ (22.3 years half-life) and ${ }^{137} \mathrm{Cs}$ (30.2 years half life) was performed. It is possible to detect radioisotope activities up to five times the half-life of the isotopes considered, which corresponds to 134 years for ${ }^{210} \mathrm{~Pb}$. ${ }^{137} \mathrm{Cs}$ is an artificial radionuclide coming from the nuclear tests made in the mid $20^{\text {th }}$ century. Activity in ${ }^{137} \mathrm{Cs}$ indicates a maximum of half a century.

Radioisotope measurements were made on bulk sediment. However, the radio-isotopes are adsorbed on fine grained particles. For cores where grain size was not constant, a correcting factor inversely proportional to the grain size was applied in order to obtain a "clayequivalent” activity.

Temporal series of currents and water turbidity were recorded at the Bourcart canyon head by deploying one mooring at $300 \mathrm{~m}$ depth within the axial incision (Fig. 2) as part of a study conducted in seven Gulf of Lions submarine canyons (Palanques et al, this volume). On that mooring, one Aanderaa RCM-9 current meter equipped with temperature, conductivity, pressure and turbidity sensors was installed at $4 \mathrm{~m}$ above the sea-floor from November 2003 to May 2004 in order to record major sediment transport events occurring during the winter season. This period was divided into two consecutive deployments. The time sampling of the 
current meters was set to 20 minutes. Temperature and conductivity sensors were calibrated using contemporary CTD measurements. Turbidity data recorded in FTU were converted into suspended sediment concentration following the methods described in (Guillén et al., 2000).

In order to estimate the capability of sand transport, the bottom shear stress $(\tau)$ associated to the observed currents is calculated under the assumption that velocity profile is logarithmic in the turbulent bottom layer (eq.1)

$\tau=\rho *[\kappa u(z) / \operatorname{Ln}(z / z 0)]^{2}($ eq. 1$)$

Where $\rho$ is the water density $\left(1027 \mathrm{~kg} \cdot \mathrm{m}^{-3}\right), \kappa$ the von Karman constant (0.4), $\mathrm{u}(\mathrm{z})$ the current velocity, $\mathrm{z}$ the height above the sea floor $(5 \mathrm{~m})$ and $\mathrm{z} 0$ the roughness length of bed surface. $\mathrm{z} 0$ ranges from $0.0002 \mathrm{~m}$ for mud to $0.006 \mathrm{~m}$ for rippled sand with $0.0007 \mathrm{~m}$ value for mud/sand complex (Soulsby, 1997). The size of particles the observed currents can move depend on the value of the bed shear stress.

\section{Results}

\subsection{Sedimentary facies}

From the combined study of sedimentological and X-ray data, it is possible to determine five facies in the collected cores from bottom to top (Fig. 4).

\subsubsection{Facies 1}

Facies 1 is characterized by stiff grey clayey silt. Under X-ray, sediments are dark grey and are composed of alternating parallel sometime disturbed laminated areas and homogeneous areas (Fig. 4)

\subsubsection{Facies 2}

Facies 2 consists of homogeneous bioturbated muddy sand. Under X-ray, this facies is made of small bright sub-rounded patches enclosed in a darker matrix (Fig. 4). Patches are interpreted to result from bioturbation activity. Faunal content analyses show that foraminifers are a mixture of reworked benthic shallow water genus (Elphidium, Ammonia), and open ocean planktic foraminifers (Globigeroïdes, Globorotalidii). Very rare ostracods and valves of juvenile bivalves are also observed. 


\subsubsection{Facies 3}

Facies 3 is defined by a shell lag in a muddy sand matrix. These sediments are too coarse for a suitable X-ray imaging, as they diffract the incident rays and give a too bright image. Despite cores taken from different physiographic settings, all samples display a very similar marine fauna, consisting of centimetric fragments of bivalves and echinoderms, gastropods and crustaceas. Abundant reworked shallow water benthic foraminifers are also observed.

\subsubsection{Facies 4}

Facies 4 is characterized by a fining upward sequence from muddy sand to sandy mud. Under $\mathrm{X}$-ray, this facies is made of large bright sub-rounded patches enclosed in a darker matrix (Fig. 4). Patches are interpreted to result from bioturbation activity and are linked to the grainsize as the size of the patches decreases with coarsening particles.

\subsubsection{Facies 5}

Facies 5 is composed of light brown sandy mud. X-ray imaging does not show any sedimentological structures but presents internal erosion surfaces, and bioturbation activity (Fig. 4).

\subsubsection{Grain-size analyses}

Facies 1 grain size data show a wide unimodal curve centered between 10 to $20 \mu \mathrm{m}$ (Fig. 4). Grain size analysis of Facies 2, 4 and 5 displays a bimodal curve with a mode in clayey silt (5 $\mu \mathrm{m})$ and the other one in medium sand (200 $\mu \mathrm{m})$ (Fig. 4). Grain size analysis of the muddy sand matrix of Facies 3 (Fig. 4) also present a bimodal curve with a minor mode of clayey silt and a major mode of medium sand.

Detailed grain size analyses performed in the fining upward succession of Facies 4, show that the fining upward trend is not linear but presents internal normal and inverse gradings. However, the overall normal grading does not typically show a shifting of the grain size curve from coarse to fine particles but results from variations in the proportion of one mode compared to the other. Grain size analyses indicate that from bottom to top of the sequence, the sand fraction (S) decreases, on average, from $60 \%$ to $20 \%$ with intra normal and inverse gradings underlined by Q index variations.

In Facies 2, on average S represents approximately 60\%, ranging from $35 \%$ to $78 \%$, and the Q index displays quite high variations both intra-core and inter-core, reaching $20 \%$ in some cases. 


\subsection{Distribution of sedimentary facies within the canyon head}

The facies described in 5.1 allow us to characterize in the study area, three different domains, proximal, central and distal in a down canyon direction; each domain is defined as an area in which similarities between cores are very strong.

\subsubsection{Proximal domain}

Proximal domain cores (KIGC10, 13, 14, 15, 16; STK10, 12, 15, 18) were sampled between 180 and 225 m water depth (Fig. 2)and are composed, from top to bottom, of muddy sand (Facies 2), a few tens of cm thick (Fig. 5A), overlying stiff grey clayey silt (Facies 1). A few cm thick shell lag (Facies 3) interrupts Facies 2 in all cores (Fig. 5A). The contact between Facies 2 and 1 is sharp or erosional. This limit is also marked by intense bioturbation in top of Facies 1 that allows unambiguously identifying this surface on all cores as a burrowed lithological contact (Fig. 5A). In these cores, S fraction values are very high (> 75\%) with a maximum in the eastern part (core STKI12 and STKI 18) where the major mode is larger and centered on $300 \mu \mathrm{m}$.

\subsubsection{Central domain}

Central domain cores (KGMO14, 15; KIGC17, 18, 19; STKI13) were collected between 225 and $330 \mathrm{~m}$ water depth (Fig. 2), the top of the cores located in the canyon axis consists of Facies 5 (very soft light brown clayey silt). They overlay a 30 to $40 \mathrm{~cm}$ thick Facies 4 . Below Facies 4, more than $1 \mathrm{~m}$ of Facies 2 interrupted by $10 \mathrm{~cm}$ of Facies 3 is observed on core KGMO14. Facies 1 represents the lowest portion of this core (Fig. 5B).

X-ray imaging of Facies 5 in core KIGC17, 19 and STKI13 allows distinguishing three subsequences separated by rough erosive contacts expressed as slight color changes on KIGC17 STKI13 and KIGC19 (Fig. 5B). Detailed grain size analyses underline a small difference between the upper two sub-sequences, expressed by a shifting of the clayey silt mode from $5 \mu \mathrm{m}$ (lower sub-sequence) to $7 \mu \mathrm{m}$ (upper sub-sequence). The contact with the underlying Facies 4 is erosive. Facies 2 present high $\mathrm{S}$ values reaching $60 \%$ to $70 \%$.

Grain size patterns downcore KIGC17, 19 and STKI13 are very similar with a neat change of grain size slope between Facies 2 and 4 (Fig. 7). X-ray imaging of KIGC17 and 19 cores shows an unclear boundary between Facies 2 and 4 but bioturbation features makes this 
boundary speculative. STKI13 core imaging reveals a gradational boundary between the two facies. In addition, in this core, X-ray clearly shows a thin bright elongated zone corresponding to a worm indicating important bioturbation processes in the area.

On the rim of the axial incision (KIGC18 and KGMO15), cores are composed of $10 \mathrm{~cm}$ of Facies 5 overlying $20 \mathrm{~cm}$ of Facies 2, interrupted at $20 \mathrm{~cm}$ by Facies 3 . These facies overlie Facies 1. Facies 5 shows internal erosion delimiting two sub-sequences (with a very unclear third one). Similarly to the canyon axis core, grain size analysis presents a shifting of the clayey silt mode from $5 \mu \mathrm{m}$ in the lower sub-sequences to $7 \mu \mathrm{m}$ in the upper one. The boundary between Facies 5 and Facies 2 is erosive. Facies $5 \mathrm{~S}$ fraction is very high and reaches 30\%, whereas it is only 35\% in Facies 2 (KIGC18).

\subsubsection{Distal domain}

Distal domain cores (KIGC20, 21, 22; STKI19, 21, STKS20) are located from 380 to 510 m water depth (Fig. 2).

In the axial incision, cores are composed (from top to bottom) of light brown silty clay (Facies 5) overlying in core STKS20 the fining upward Facies 4 and stiff grey silty clay (Facies 1) or directly lying on Facies 1 in core KIGC20 (Fig. 5C).

$\mathrm{X}$-ray imaging of STKI 19 reveals two sequences in Facies 5. The upper sequence is $30 \mathrm{~cm}$ thick, structureless in the upper $25 \mathrm{~cm}$ and displaying rough parallel laminations from 25 to $30 \mathrm{~cm}$. The lower sequence shows in the first $10 \mathrm{~cm}$ (from 30 to $40 \mathrm{~cm}$ ) inclined parallel laminations (Fig. 5C). The two sequences present two main differences. Firstly, S values are very low $(<10 \%)$, but lower in the upper sequence (average at $2 \%$ ) than in the lower sequence (average at $6 \%$ ). Secondly, there is a shift of the clayey silt mode from $5 \mu \mathrm{m}$ in the upper sequence to $7 \mu \mathrm{m}$ in the lower sequence.

Looking at the core transect KIGC20/KIGC21/KIGC22 (Fig. 2), KIGC21 and KIGC22 sediments are composed of Facies 5 overlying Facies 4. Facies 4 thickness increases from the axis of the incised channel to its flank (from $20 \mathrm{~cm}$ in KIGC20 to reach $75 \mathrm{~cm}$ in KIGC22). Inside the overall fining upward Facies 4, fining and coarsening upward patterns are observed. X-ray imaging of KIGC21 shows that these patterns correspond to darker areas for coarser sediments and brighter areas for finer sediments. These areas are interpreted to be separated by very bioturbated erosive contacts. However, extensive bioturbation processes destroyed 
similar information within KIGC22 core. S fraction in Facies 4 is low ranging from $38 \%$ to 23\% in KIGC21 and 50\% to 20\% in KIGC22.

\subsection{Radio-isotope measurements}

Radio-isotope measurements performed on key cores allowed dating of the sampled sediments. The top sediments of each core present high ${ }^{210} \mathrm{~Pb}_{\text {exc }}$ activity and significant ${ }^{137} \mathrm{Cs}$ values which suggests an age younger than 50 years (Fig. 5).

Further analyses performed downcore STKI12 (Fig. 5A) display a logarithmic decrease of ${ }^{210} \mathrm{~Pb}_{\text {exc }}$ activity within the upper $10 \mathrm{~cm}$ of the muddy sand facies. This indicates an age of deposition younger than 134 years. In addition, ${ }^{137} \mathrm{Cs}$ activity (between 5 and $8 \mathrm{~Bq} / \mathrm{kg}$ ) in the upper $5 \mathrm{~cm}$ of sediment suggest they were deposited less than 50 years ago. Identical analysis downcore STKI18 confirm this time range.

Core STKI13 has high ${ }^{210} \mathrm{~Pb}_{\text {exc }}$ values in the upper sequence, and shows evidence for the two main sub-sequences identified in STKI13 Facies 5 in the central domain (Fig. 5B). Accumulation rates are $0.47 \mathrm{~cm} / \mathrm{y}$ for the upper sub-sequence and $0.18 \mathrm{~cm} / \mathrm{y}$ for the lower sub-sequence.

${ }^{210} \mathrm{~Pb}_{\text {exc }}$ values in core STKI19 slowly decrease from the top of the core down to $30 \mathrm{~cm}$ (Fig. 4C). Below $30 \mathrm{~cm}$, no ${ }^{210} \mathrm{~Pb}_{\text {exc }}$ is measured. Down canyon, measurements of ${ }^{210} \mathrm{~Pb}_{\text {exc }}$ in the STKI21 core display constant high activity along the $30 \mathrm{~cm}$-long core.

An indirect way of dating was provided by a small piece of plastic material, identified to belong to some plastic bag, recovered at $7 \mathrm{~cm}$ below surface, within Facies 2 (massive muddy sand) in core STKI15. This implies an age less than about 50 years, consistent with ages indicated by ${ }^{210} \mathrm{~Pb}_{\text {exc }}$ measurements.

\subsection{Depositional units}

The combination of X-ray imaging grain size analysis and radio-isotope measurements allow the defining of three main depositional units along the canyon course (Fig. 6). Despite different lithologies, the sediments deposited within each unit at different water depth are considered as coeval. These units are best developed in the central domain, where correlations are possible from core to core. 
The upper unit, A, corresponds to sediments younger than 134 years, where radioisotope activities are detected (Fig. 6). In the proximal domain the basal limit is only a timeline that is not supported by any sedimentological features. In the central and distal domains, the radionuclide activities limit corresponds to an erosive boundary that separates very different facies either in terms of X-ray response or in terms of grain size patterns.

This unit is composed of Facies 2 in the proximal domain. In the central domain unit A consists of Facies 5 overlying Facies 2 on the canyon rim and of Facies 5 within the axial channel. In the distal domain unit A is composed of Facies 5. Facies are separated by erosive contacts and internal erosive surfaces are observed within Facies 5. Erosive boundaries are preserved within central and distal domain fine-grained sediments but no erosive features are observed in coarse-grained proximal domain sediments. Unit A thickens with increasing depth, from $10 \mathrm{~cm}$ in the proximal domain to $30 \mathrm{~cm}$ in the distal domain. Along the incised channel, this unit progressively changes from massive muddy sand to sandy silt and then to silt in a downward direction.

Unit B corresponds to sediments older than 134 years. Unit B is characterized by (1) reworked material, (2) the occurrence of a coarse shell lag within the proximal and central domain, (3) very consistent grain size patterns in central and distal domain (shown by detailed grain size analyses in Fig. 7, and (4) little evidence of internal structures (erosion or bedforms). Unit B is composed from bottom to top of Facies 2 (containing Facies 3), Facies 4 and Facies 5. In the proximal domain, only Facies 2 and Facies 3 are present and the unit thickness is up to a few tens of $\mathrm{cm}$. This unit reaches its maximum thickness $(1.5 \mathrm{~m})$ in the central domain where Facies 2 to 4 are observed. Down canyon, the bottom coarser part (Facies 2 and Facies 3) progressively disappears, together with an overall fining of Facies 4 (Fig. 6 and 7) and the progressive development of Facies 5.

Unit C is made of Facies 1, its upper limit is an erosion surface. This unit is observed in every core and constitutes the basal unit in this area (Fig. 6).

\subsection{Mooring data}

The current meter recorded several episodes of variable near-bottom current velocities ( $>0.2 \mathrm{~m} / \mathrm{s}$ ). The highest velocities (up to $0.37 \mathrm{~m} / \mathrm{s}$ ) corresponded to cascading of cold water 
formed on the shelf during episodes of strong winds. These cascading events are clearly shown in the temperature and current direction records (Fig. 8A). Important temperature decreases are observed in early February, late February, mid March, early April, mid April and early May. They lasted between a few days and two weeks. The first two events in early February were associated with $\mathrm{N}$ and NW winds, but the following ones started during an eastern storm that produced waves from 3 to $7 \mathrm{~m}$ high near the coast and caused downwelling (Palanques et al., this volume). In the Bourcart Canyon the longer cascading events occurred in March and Early April, and the more intense one was in March. (Fig. 8A). All these cascading events were recorded simultaneously throughout the Gulf of Lions, with much higher near-bottom current velocities (from 0.6 to $0.8 \mathrm{~m} / \mathrm{s}$ ) in the western canyons (Cap de Creus, Lacaze-Duthiers) (Palanques et al., this volume). In the Bourcart canyon some of these events were correlated with increases of suspended sediment concentration ranging from 0.5 to $5.5 \mathrm{mg} \mathrm{l}^{-1}$. However, the event that produced higher current speeds and suspended sediment concentrations was the one occurring in late February associated with an extremely strong eastern storm that generated waves higher than $7 \mathrm{~m}$ and lasted about 3 days. The currents with highest velocities were oriented toward SE (N135, Fig. 8B) corresponding to the down channel direction at the position of the mooring (Fig. 2).

In addition to the cascading process, there were also some episodes in December and January during which current velocities increased up to $0.25 \mathrm{~m} / \mathrm{s}$ in the up canyon direction (NW) suggesting upwelling. An episode of downwelling of warmer water was also observed in relation to the major easterly storm that occurred in early December, 2003 (Palanques et al., this volume). In the Bourcart canyon this episode induced increases of current velocities (up to $0.25 \mathrm{~m} / \mathrm{s}$ ) as well as slight suspended sediment concentration (SSC) increases.

The calculation of the bottom shear stress for the peak current $(0.37 \mathrm{~m} / \mathrm{s})$ is very dependent on the roughness length (z0) utilized for the calculation. Therefore, we did the calculation for a broad range of roughness values, corresponding to mud (lowest $\mathrm{z} 0$ ) to rippled sands (highest z0) (Soulsby, 1997). The resulting shear stress ranges from $0.20 \mathrm{~N} / \mathrm{m}^{2}$ to $0.53 \mathrm{~N} / \mathrm{m}^{2}$ (Fig. 9). Such shear stresses are large enough to erode particles ranging from $0.35 \mathrm{~mm}$ to $1.02 \mathrm{~mm}$ respectively, as calculated for sea water temperature and salinity similar to our study area (Fig. 21 of (Soulsby, 1997)). 


\section{Discussion}

\subsection{Evidence for coarse-grained sediment deposition and by-passing within the Bourcart canyon head during the Holocene}

Unit C (Fig. 6) corresponds to our basal unit and interpreted to result from alternating finegrained turbidites and hemipelagic fallout. Using chirp seismic profiles shot in the canyon head and on the Bourcart/Hérault interfluve, it is possible to correlate unit C to units U151, U152 or U154 of Jouët et al., (this volume), dated between 28 and 15 cal kyr BP. This timeinterval is characterized, within the canyon head, by a very high sedimentation rate, because of the vicinity of fluvial systems.

Unit A and B present completely different patterns compared to unit C. The analyses performed on the sediment suggest that they come from the same source area and most likely that they resulted from reworking of littoral sands of the Last Glacial shoreline, situated along the $120 \mathrm{~m}$ bathymetric contour line, mixed with offshore muds. The sand fraction that compose units A and B is similar to the Holocene "mobile carpet" that reworks the LGM shoreface during periods of high energy, especially those related to easterly winds (Bassetti et al, this volume), see 6.2.2.

\subsection{Potential sediment transport mechanisms}

The possible mechanisms for sediment transport in the Bourcart canyon head are (a) gravity processes, (b) the impact of a geostrophic contour current (the Northern Current), (c) bottom currents induced by easterly winds, and (d) cascading events.

\subsubsection{Gravity flows}

In present day highstand conditions in the Gulf of Lions, gravity flows are not believed to be significant features at shelf edge, especially in the Bourcart canyon head located $70 \mathrm{~km}$ off direct continental inputs. In situ geotechnical measurements carried out around the canyon head demonstrated that the upper $2 \mathrm{~m}$ of sediment are constituted by stable over-consolidated material not prone to failure (factor of safety $>1$ ) (Sultan et al., Accepted). In addition, detailed bathymetric and seismic data do not exhibit any slump scar cutting across sediments younger than 20 kyr (Jouët et al., this volume). 


\subsubsection{Intensification of the Northern Current}

Detailed studies aiming to characterize the NC showed that the intensification of the NC can produce current velocities of $0.5 \mathrm{~m} / \mathrm{s}$ at a depth of $200 \mathrm{~m}$ in the water column (Petrenko, 2003). This author also shows the role of sea-floor morphology in the orientation of the current, with up-canyon currents observed in the Bourcart canyon, but no measurement of current velocities are available for the sea-floor. However upcanyon-downcanyon current inversions are observed at the present time. The frequency of these inversions is variable, with a 6-10 day periodicity observed in the Foix Canyon associated with passage of atmospheric pressure cells (Puig et al., 2000) or a 3 day periodicity (Palamós canyon) associated with topographic waves (Jordi et al., in press; Palanques et al., in press). This periodic process could be explained by the meandering of the Northern Current, as the wavelength and the period of the meanders have been estimated as 30-60 km and 3-6 days respectively (Sammari et al., 1995). These processes could be at the origin of up-canyon currents of up to $0.25 \mathrm{~m} / \mathrm{s}$ recorded between mid-December and the end of January (Fig. 8A).

\subsubsection{Intensification of shear stress during easterlies}

Model analysis (André et al., 2005); (Bassetti et al, this volume) suggests that, under the influence of constant wind from the east, intense bottom currents can be produced in the coastal zone, as expected, and also in the westernmost area of the shelf and at the shelf break. This model also indicates that, for the entire Gulf of Lions, the maximum bed shear stress created by these events occurs in a zone situated immediately upstream of the Bourcart canyon (Bassetti et al., this volume). The maximum shear stress on the bed is predicted at the beginning of the events, reaching maximum values of $0.24 \mathrm{~N} / \mathrm{m}^{2}$ in the area of sand dunes situated between 90 and 100 m water depth. The simulation of the bottom currents during several days demonstrates that the tensions become progressively weaker on a 7 day time frame, whereas the zone of maximum shear stress moves as the area of highest bottom shear stress is moving toward the SW. The shear stress on the bed is probably also increased by the combined effect of large swells generated by easterlies reinforcing near-bed currents. This process induces large enough bottom stresses to erode medium-grained sand on the outer shelf (Bassetti et al., this volume). 


\subsubsection{Dense water cascading}

Cascading events of variable intensity constitute classical features of Gulf of Lions hydrodynamic (Durrieu de Madron et al., 2005). Bethoux et al. (2002) identified four major cascading events over the 1971-2000 period, contributing to the formation of western Mediterranean deep water. During the last major event, that lasted from February 24 and March 12, 1999, cold water cascading in the Lacaze Duthiers canyon produced up to $0.6 \mathrm{~m} / \mathrm{s}$ current velocities at $1000 \mathrm{~m}$ water depth (Bethoux et al., 2002). In the Cap de Creus canyon, during 2004-2005 winter, cascading events maintained from late January to early March down canyon steady currents between $0.4 \mathrm{~m} / \mathrm{s}$ and $0.8 \mathrm{~m} / \mathrm{s}$ down to $750 \mathrm{~m}$ water depth (Puig et al., 2005).

The importance of cascading, even in the less energetic Bourcart canyon, is confirmed by our mooring data that show several week lasting events during 2003-2004 winter period. Currents velocities are less than $0.2 \mathrm{~m} / \mathrm{s}$ in average and therefore too low to account for erosion and transport of coarse-grained particles (Fig. 8 and 9). However peak currents can reach up to $0.37 \mathrm{~m} / \mathrm{s}$ for a few hours and produce large enough bottom shear stress to erode and transport medium-grained sand.

Nevertheless current velocities measured at the same time in the Cap de Creus and Lacaze Duthiers canyons with peak velocities up to $0.8 \mathrm{~m} / \mathrm{s}$ (Palanques et al., this volume) suggest that larger velocities can be expected in the Bourcart canyon head during colder winters, such as the 2004-2005 one.

In summary, cascading events are considered as being at the origin of the observed sand beds, as they can produce high velocity and long lasting currents in the Bourcart canyon head.

\subsection{Sediment deposition in the canyon head}

\subsubsection{Sediments younger than 134 years}

Radioisotope measurements performed in the cores show that unit A corresponds to deposits accumulated during the last 134 years. Erosive contacts are remnant imprints of these multiple depositional events. Down canyon, the unit presents a fining trend: Muddy sand found in the proximal domain correlates to sandy silt and silt in the central and distal domains, respectively. Cold water cascading events similar to those recorded in the 2003-2004 winter possibly triggered and/or enhanced by easterly winds (Bassetti et al., this volume: Palanques 
et al. this volume) are presumed to be the driving force for sediment transport down the canyon as they have a shelf origin and are known to produce high current velocities.

Depending on intensity of these events they can transport and accumulate sands from the outer shelf into the canyon head or they can even resuspend and erode sands deposited by previous events.

During the winter cascading season and the eastern storms, the proximal domain acts as a depocentre for medium-grained sediments. Bottom currents are large enough but not sustained enough to transport sand further down than the uppermost part of the canyon head. The central and distal domains constitute bypass or erosive areas as fine-grained sediments are winnowed away by the strong currents.

During the rest of the year, currents are lower and only fine-grained sediments are transported. This could be the fine fraction that is contained in the sediment within the unit A. From our data, it is not possible to determine whether the muddy sand and its time correlative sandy silt and silt result from one or more mechanisms that acted during the last 134 years.

In any case, the sediments that compose unit A are considered to be the imprint of shelf-break and upper slope modern hydrodynamic conditions and constitute the background sedimentation for the last 134 years in the canyon head. The presence of erosive features, especially in the fine material, evidences that this modern sedimentary activity is made of alternative phases of deposition and erosion.

\subsubsection{Massive sand beds}

Unit B comprises sediments that are older than 134 years and younger than the underlying Pleistocene deposits. This unit consists of massive (up to $1.50 \mathrm{~m}$ thick) homogeneous medium-grained sand, including a distinct shell lag observed on all cores of the proximal and central domains overlain by a fining upward sequence. These sedimentary facies imply large enough long lasting steady currents reaching velocities higher than $0.35 \mathrm{~m} / \mathrm{s}$ (Fig. 9), similar to those measured in the Cap de Creus canyon (Puig et al., 2005). Considering the limited time constraint, we may propose two scenarios for the deposition of massive sand beds.

\subsubsection{Mono-event hypothesis}

The first scenario suggests that the unit B corresponds to one strong single cascading event, lasting from a few days to several weeks. 
From bottom to top of the sand bed, the coarsening upward (including the shell lag) would be formed by a waxing (accelerating with time) flow (Kneller, 1995) (KIGC19/KGMO14 cores on Fig. 5 or 6). This flow is also depletive (decelerating with distance), as demonstrated by the down-canyon fining trend. The maximum flow velocity, probably linked to a burst of current similar to that observed on the mooring during the cascading events (Fig. 8), would result in erosion followed by deposition of the shell lag. Afterwards, the flow velocity decreased progressively (overall fining upward) but remained strong enough to transport medium sand. Within this overall fining upward interval, episodes of increasing and decreasing flow can be inferred from grain-size changes. The episodes can be correlated from core to core in the distal and central domain thanks to very similar changes in X-ray facies and grain size (Fig. 3 and 7). The central domain acts as the main depocentre for mediumgrained sand.

This scenario implies that exceptional cascading events may occur at a scale larger than the century. During such exceptional events all sediments previously deposited above the Pleistocene mud (unit C) were eroded.

\subsubsection{Multi-events hypothesis}

In this scenario, unit B represents the stacking of sand beds deposited by several major cascading events that occurred during the Holocene.

Above the Pleistocene mud, the deposition of Facies 2 muddy sand results from the stacking of several beds that cannot be distinguished from each other because of (1) subsequent bioturbation, (2) similar sources of sediment for each event. The proximal and especially the central domain act as sand depocentres whereas the distal domain constitutes a bypass or erosive area. The shell lag (Facies 3) would correspond to the peak flow velocity. During this period, strong currents prevented sand deposition, the canyon head constituting a bypass zone where only shells remained. The shell lag also preserved the underneath sediment from erosion because of its “armouring effect”. The Bourcart canyon situation at this time was similar to the present day Cap de Creus and Lacaze Duthiers canyons situations.

The transition of Facies 2 to 4 and finally 5 is linked to a reduction of the intensity of cascading events with internal grain size variations marking different events. The deceleration of average cascading event velocity can be related to historical changes, at unknown time scale. However, detailed analysis of a long core on the Bourcart/ Hérault interfluve (core MD992348) shows that sedimentation was affected by secular variations in the temperature 
with a magnitude of $3-5^{\circ} \mathrm{C}$ and periodicities of 250 and 750 years (Flores et al., 2005). These fluctuations in sea-water temperature, that are linked by these authors to fluctuations of the polar circulation index (Mayewski et al., 1994), certainly have an impact on deep-water formation and cascading as observed nowadays.

\subsection{Cascadites}

Cascading events constitute the driving force for present day sedimentary activity within the western Gulf of Lion shelf. This process is at the origin of a massive sand bed observed in the Bourcart canyon head. In fact, this sand bed is also observed on one interface core sampled at $135 \mathrm{~m}$ water depth on the Bourcart-Hérault canyon interfluve. These sands constitute a new type of deposits that could be named "cascadites", by comparison with other slope deposits such as turbidites, hyperpycnites, or contourites. Cascadites, in our study area, differ from turbidites and hyperpycnites as they show a bimodal grain size pattern that could not be explained by typical waxing and/or waning flows. The two grain size modes probably underline the sudden variations in current velocity during the general waxing and waning pattern of the cascading event as shown in Fig. 8. The sedimentological characteristics of cascadites and their location at relatively shallow water depths (between 160 and $520 \mathrm{~m}$ in our case) suggest that cascadites are more similar to shallow water contourites, named shallowwater bottom-current sands by Viana et al. (1998).The diagnostic features of cascading sequences and their comparison to other slope deposits is summarized in Table 1 (modified from Mulder et al. (2002). However, our data do not show peculiar structures allowing a better discrimination between cascadites and shallow-water bottom current sand. More examples are needed to characterize the nature of cascading induced bottom currents and to detail the structure of cascadite deposits.

Another open question is to know how such cascadites may evolve downslope into "regular" gravity deposits. During intensification of cascading events, transported sediments bypass the upper slope and continue their route downslope as recorded at $1000 \mathrm{~m}$ water depth in the Lacaze Duthiers canyon (Bethoux et al., 2002). The downslope flow which erodes and transports sediments can than evolve into a typical turbidity flow. This process could be one of the processes at the origin of Holocene sandy deposits described on the Rhone neofan at 2500 m water depth (Bonnel et al., 2005), and of ${ }^{210} \mathrm{~Pb}_{\text {exc }}$ activity recorded in the PyreneoLanguedocian Sedimentary Ridge that drains the western Gulf of Lions submarine canyons (Buscail et al., 1997). 


\section{Conclusion}

The analysis of interface cores recovered in the head of the Bourcart canyon shows that this part of the Gulf of Lions shelf is presently subject to active sedimentary processes. Although the Bourcart canyon head is located at $110 \mathrm{~m}$ water depth and is considered to have a shape inherited from the Last Glacial Maximum, this study demonstrates the presence of modern deposits blanketing of the study area down to a depth of $400 \mathrm{~m}$. These deposits consist of muddy sand to clayey silt sediments, the coarse-grained fraction probably originating from the erosion of the LGM lowstand shoreface sands and transgressive deposits situated immediately upstream, whereas the fine-grained part corresponds either to suspended sediment supplied by rivers and/or reworked slope deposits. Massive sand beds are interpreted as the result of sediment transport and deposition during periods of dense water cascading at the shelf edge. They represent a new type of deposit (“cascadite”) that differs from slope gravity deposits such as turbidites in that they are more likely to form during highstands of sea-level, when dense cold water may form on a broad continental shelf. But in our study their structure cannot be differentiated from shallow water bottom current sand. The canyon head represents a preferential pathway for reworked sediments transiting from the outer shelf to the deep sea, as demonstrated by the thicker sand accumulation observed within the meandering axial incision.

\section{Acknowledgements}

The data were acquired within the European projects "Eurostrataform” (contract EVK3-200100200), PROMESS 1 (contract EVR1-CT-2002-40024) and the French Agence Nationale de la Recherche (ANR, contract NT05-3-42040). Initial support was provided by Ifremer and the French "Margins” program. Captains and crews of "Le Suroît” and “L’Europe” are thanked for assistance during cruises Calmar 99, Strataform, GMO1 and GMO2. Nabil Sultan gave access to the GMO2 data. The technical staffs of Genavir (data acquisition) and Ifremer GM (data processing) are warmly thanked (A.S. Alix, R. Apprioual, F. Duval, G. Floch, N. Frumholtz, E. Le Drezen, B. Loubrieu, A. Normand, C. Satra). B. Dennielou is thanked for discussions about cascadites and F. Dufois for discussions on bottom shear stress calculations. This is an UM5805 EPOC contribution $n^{\circ} \ldots$... MG scholarship is provided by Total and Ifremer. We thank C.K Paull and K.H Kenyon for their constructive reviews and comments. 


\section{References}

Aloïsi, J.-C., 1986. Sur un modèle de sédimentation deltaïque:Contribution à la connaissance des marges passives. PhD thesis, University of Perpignan (162 pp).

André, G., Garreau, P., Garnier, V. and Fraunié, P., 2005. Analysis of the surface circulation in the Northwestern Mediterranean Sea using a combination of AVHRR satellite measurements and MARS-3D model. Ocean Dynamics, in press.

Ardhuin, F., Pinot, J. and Tintoré, J., 1999. Numerical study of the circulation in a steep canyon off the Catalan coast (western Mediterranean). J. Geophys. Res., 104((C5)): 11115-11136.

Bassetti, M.A. Jouët, G., Dufois, F., Berné, S., Rabineau, M. Taviani, M., submitted. Deglacial sedimentary processes and deposits in the outer continental shelf of the Gulf of Lions (western Mediterranean). Marine Geology.

Baztan, J., Berné, S., Olivet, J-L., Rabineau, M., Aslanian, D., Gaudin, M., Réhault, J-P., Canals, M., 2005. Axial incision: the key to understand submarine canyon evolution (in the western Gulf of Lion). Marine and Petroleum Geology, 22(6-7): 805-826.

Berné, S., Lericolais, G., Marsset, T., Bourillet, J.F. and de Batist, M., 1998. Erosional shelf sand ridges and lowstand shorefaces. Examples from tide and wave dominated environments of France. Journal of Sedimentary Research, 68((4)): 540-555.

Berné, S. and Loubrieu, B., 1999. Canyons and recent sedimentary processes on the western Gulf of Lions margin. First results of the Calmar cruise. Comptes Rendus de l'Académie des Sciences - Séries IIA - Earth and Planetary Science, 328(7): 471-477.

Berné, S., Rabineau, M., Flores, J.A. and F.J., S., 2004. The impact of Quaternary global changes on strata formation. Oceanography, 17(4): 92-103.

Berné, S., Satra, C., Aloïsi, J.C., Baztan, J., Dennielou, B., Droz, L., Dos Reis, A.T., Lofi, J., Méar, Y., Rabineau, M., 2002. Carte morpho-bathymétrique du Golfe du Lion, notice explicative. Ifremer, Brest.

Bethoux, J.P., Durrieu de Madron, X., Nyffeler, F. and Tailliez, D., 2002. Deep water in the western Mediterranean: peculiar 1999 and 2000 characteristics, shelf formation hypothesis, variability since 1970 and geochemical inferences. Journal of Marine Systems, 33-34: 117-131.

Bonnel, C., Dennielou, B., Droz, L., Mulder, T. and Berne, S., 2005. Architecture and depositional pattern of the Rhone Neofan and recent gravity activity in the Gulf of Lions (western Mediterranean). Marine and Petroleum Geology: 1-17.

Buscail, R., Ambatsian, P., Monaco, A. and Bernat, M., 1997. 210Pb, manganese and carbon: indicators of focusing processes on the northwestern Mediterranean continental margin. Marine Geology, 137(3-4): 271-286.

Durrieu de Madron, X., 1992. Hydrography and nepheloid structures in the Grand-Rhône canyon. Continental Shelf Research: pp.457-477.

Durrieu de Madron, X., Zervakis, V., Theocharis, A. and Georgopoulos, D., 2005. Comments on "Cascades of dense water around the world ocean". Progress In Oceanography, 64(1): 83-90.

Flores, J.A., Sierro, F.J., Pérez-Folgado, M., Gravalosa, J.M., Barcena, M.A., ColmeneroHidalgo, M.A.E., Grimalt, J., Berné, S., Dennielou, B., Curtis, J.H., Hodell, D.A., and the PROMESS 1 on board party, 2005. Millennial to centennial abrupt climatic changes during the last climatic cycles in the Gulf of Lions revealed by micropaleontological and biogeochemical proxies. Joint EUROSTRATAFORM/PROMESS meeting, Salamanca, 24-27 October, 2005.

Frignani, M., Courp, T., Cochran, J.K., Hirschberg, D. and Vitoria i Codina, L., 2002. Scavenging rates and particle characteristics in and near the Lacaze-Duthiers 
submarine canyon, northwest Mediterranean. Continental Shelf Research, 22(15): 2175-2190.

Garfield, N., Rago, T.A., Schnebele, K.J. and Collins, C.A., 1994. Evidence of a turbidity current in Monterey Submarine Canyon associated with the 1989 Loma Prieta earthquake. Continental Shelf Research, 14(6): 673-686.

Guillén, J., Palanques, A., Puig, P., Durrieu de Madron, X. and Nyffeler, F., 2000. Field calibration of optical sensors for measuring suspended sediment concentration in the western Mediterranean. Scientia Marina, 64((4)): 427-435.

Ivanov, V.V., Shapiro, G.I., Huthnance, J.M., Aleynik, D.L. and Golovin, P.N., 2004. Cascades of dense water around the world ocean. Progress In Oceanography, 60: 4798.

Jordi, A., Orfila, A., Basterretxea, G. and Tintore, J., in press. Shelf-slope exchanges by frontal variability in a steep submarine canyon. Progress In Oceanography, 2005.

Jouanneau, J.M., Weber, O., Drago, T., Rodrigues, A., Oliveira, A., Dias, J. M. A., Garcia, C., Schmidt, S., Reyss, J. L., 2002. Recent sedimentation and sedimentary budgets on the western Iberian shelf. Progress In Oceanography, 52(2-4): 261-275.

Jouët, G. Berné, S., Rabineau, M., Bassetti, M.A., Bernier, P., Dennielou, B., submitted. Shoreface migrations at the shelf edge and sea-level changes around the Last Glacial Maximum (Gulf of Lions, NW Mediterranean). Marine Geology.

Kenyon, N.H., 1986. Evidence from bedforms for a strong poleward current along the upper continental slope of northwest Europe. Marine Geology, 72(1-2): 187-198.

Khripounoff, A., Vangriesheim, A., Babonneau, N., Crassous, P., Dennielou, B., Savoye, Bruno, 2003. Direct observation of intense turbidity current activity in the Zaire submarine valley at $4000 \mathrm{~m}$ water depth. Marine Geology, 194(3-4): 151-158.

Kneller, B., 1995. Beyond the turbidite paradigm: physical models for deposition of turbidites and their implications for reservoir prediction. In: Hartley AJ, Prosser DJ (eds) Characterization of deep marine clastic systems. Geol Soc Lond Publ, 94: 31-49.

Lapouyade, A. and Durrieu De Madron, X., 2001. Seasonal variability of the advective transport of particulate matter and organic carbon in the Gulf of Lion (NW Mediterranean). Oceanologica Acta, 24(3): 295-312.

Lewis, K.B. and Barnes, P.M., 1999. Kaikoura Canyon, New Zealand: active conduit from near-shore sediment zones to trench-axis channel. Marine Geology, 162(1): 39-69.

Liu, J.T. and Lin, H.-l., 2004. Sediment dynamics in a submarine canyon: a case of river-sea interaction. Marine Geology, 207(1-4).

Lofi, J., Rabineau, M., Gorini, C., Berne, S., Clauzon, G., De Clarens, P., Tadeu Dos Reis, A., Mountain, Gregory S., Ryan, William B. F., Steckler, M. S., Fouchet, C., 2003. PlioQuaternary prograding clinoform wedges of the western Gulf of Lion continental margin (NW Mediterranean) after the Messinian Salinity Crisis. Marine Geology, 198(3-4): 289-317.

Mayewski, P.A., Meeker, L.D., Whitlow, S., Twickler, M.S., Morrison, M.C., Grootes, P.M., Bond, G.C., Alley, R.B., Meese, D.A., Gow, A.J., Taylor, K.C., Ram, M., Wumkes, M., 1994. Changes In Atmospheric Circulation and Ocean Ice Cover Over the North Atlantic During the Last 41,000 Years. Science, 263: 1747-1751.

Migeon, S., Weber, O., Faugères, J.-C., and Saint-Paul, J., 1999. SCOPIX: A new X-ray imaging system for core analysis. Geo-Marine Letters, 18(3): 251-255.

Millot, C., 1990. The Gulf of Lions' hydrodynamics. Continental Shelf Research, 10(9-11): 885-894.

Millot, C., 1991. Mesoscale and seasonal variabilities of the circulation in the Western Mediterranean. Dyn. Atmos. Oceans, 15: 179-214. 
Mulder, T., Migeon, S., SAVOYE, B. and Faugères, J.-C., 2002. Reply to discussion by Shanmugam on Mulder et al. (2001, Geo-Marine Letters 21: 86-93) Inversely graded turbidite sequences in the deep Mediterranean. A record of deposits from floodgenerated turbidity currents? Geo-Marine Letters, 22(2): 112-120.

Mulder, T., Weber, O., Anschutz, P., Jorissen, F.J. and Jouanneau, J.-M., 2001. A few months-old storm generated turbidite deposited in the Capbreton Canyon (bay of Biscay, SW France). Geo-Mar Lett, 21(3): 149-156.

Mullenbach, B.L. and Nittrouer, C.A., 2000. Rapid deposition of fluvial sediment in the Eel Canyon, northern California. Continental Shelf Research, 20(16): 2191-2212.

Mullenbach, B.L., Nittrouer, C.A., Puig, P. and Orange, D.L., 2004. Sediment deposition in a modern submarine canyon: Eel Canyon, northern California. Marine Geology, 211(12): 101-119.

Palanques, A., Palanques, A., Durieu de Madron, X., Puig, P., Fabres, J., Guillen, J., Calafat, A. M., Canals, M., Bonnin, J., submitted. Suspended sediment fluxes and transport processes in the Gulf of Lions submarinecanyons. The role of storms and dense water cascading. Marine Geology.

Palanques, A., Garcia-Ladona, E., Gomis, D., Martin, J., Marcos, M., Pascual, A., Puig, P., Gili, J-M., Emelianov, M., Monserrat, S., in press. General patterns of circulation, sediment fluxes and ecology of the Palamos (La Fonera) submarine canyon, northwestern Mediterranean. Progress In Oceanography, In Press, Corrected Proof.

Paull, C.K., Mitts, P., Ussler, W.I., Keaten, R. and Greene, H.G., 2005. Trail of sand in upper Monterey Canyon: Offshore California. Geological Society of America Bulletin, 117(9): 1134-1145.

Paull, C.K., Ussler III, W., Greene, H.G., Keaten, R., Mitts, P., Barry, J., 2003. Caught in the act: the 20 December 2001 gravity flow event in Monterey Canyon. Geo-Mar Lett, 22: 227-232.

Petrenko, A.A., 2003. Variability of circulation features in the Gulf of Lion NW Mediterranean Sea. Importance of inertial currents. Oceanologica Acta, 26(4): 323338.

Posamentier, H.W., Allen, G.P., James, D.P. and Tesson, M., 1992. Forced regression in a sequence stratigraphic framework: concepts, examples, and exploration significance. AAPG Bullettin, 76: 1687-1709.

Puig, P., Ogston, A.S., Mullenbach, B.L., Nittrouer, C.A. and Sternberg, R.W., 2003. Shelfto-canyon sediment-transport processes on the Eel continental margin (northern California). Marine Geology, 193(1-2): 129-149.

Puig, P., Palanques, A. and Guillen, J., 2005. Shelf water cascading and sediment transport processes through the Cap de Creus submarine canyon. Joint EUROSTRATAFORM/PROMESS meeting, Salamanca, 24-27 October, 2005.

Puig, P., Palanques, A., Guillen, J. and Garcia-Ladona, E., 2000. Deep slope currents and suspended particle fluxes in and around the Foix submarine canyon (NW Mediterranean). Deep-Sea Research Part I: Oceanographic Research Papers, 47(3): 343-366.

Rabineau, M., 2001. Un modèle géométrique et stratigraphique des séquences de dépôts quaternaires de la plate-forme du Golfe du Lion : enregistrement des cycles glacioeustatiques de 100000 ans. Ph. D. Thesis, Université de Rennes 1: 445 pp.

Sammari, C., Millot, C. and Prieur, L., 1995. Aspects of the seasonal and mesoscale variabilities of the Northern Current in the western Mediterranean Sea inferred from the PROLIG-2 and PROS-6 experiments. Deep Sea Research Part I: Oceanographic Research Papers, 42(6): 893-917. 
Segall, M.P., Kuehl, S.A. and Gipson, J., M., 1989. Clay-size minerals as indicators of modern sedimentary processes in submarine canyons: Application to the Wilmington Canyon System. Marine Geology, 90(3): 175-192.

Shanmugam, G., 2003. Deep-marine tidal bottom currents and their reworked sands in modern and ancient submarine canyons. Marine and Petroleum Geology, 20(5): 471491.

Shepard, F.P. and Dill, R.F., 1966. Submarine canyons and other sea valleys. Rand McNally Comp, Chicago: $381 \mathrm{p}$.

Shepard, F.P. and Marshall, N.F., 1973. Storm-generated current in La Jolla Submarine Canyon, California. Marine Geology, 15(1): M19-M24.

Snyder, G.W. and Carson, B., 1986. Bottom and suspended particle sizes: Implications for modern sediment transport in Quinault submarine canyon. Marine Geology, 71(1-2): 85-105.

Soulsby, R.L., 1997. Manual of marine sands. HR Wallingford, Thomas Telford publications: 249.

Sultan, N., Gaudin, M., Berné, S., Canals, M., Urgeles, R., Lafuerza, S., Accepted. Analysis of slope failures in canyon heads: example from the Gulf of Lions. Journal of Geophysical Research.

Thorbjarnarson, K.W., Nittrouer, C.A. and DeMaster, D.J., 1986. Accumulation of modern sediment in Quinault submarine canyon. Marine Geology, 71(1-2): 107-124.

Viana, A.R., Faugères, J.-C., and Stow, D.A.V., 1998. Bottom-current-controlled sand deposits -- a review of modern shallow- to deep-water environments. Sedimentary Geology, 115(1-4): 53-80.

Xu, J.P., Noble, M., Eittreim, S. L., Rosenfeld, L. K., Schwing, F. B., Pilskaln, C. H., 2002. Distribution and transport of suspended particulate matter in Monterey Canyon, California. Marine Geology, 181(1-3): 215-234.

\section{Figure captions}

Fig. 1: Bathymetric map of the Gulf of Lions and position of the study area on the outer shelf (Fig. 2). CdC, Cap de Creus, LDC, Lacaze-Duthiers Canyon; PvC, Pruvot Canyon; BC, Bourcart Canyon; HC, Hérault Canyon; SC, Sète Canyon; MaC, Marti Canyon; PRC, PetitRhône Canyon; GRC, Grand- Rhône Canyon; EC, Estocade canyon.

Fig. 2: Bathymetric map of the Bourcart canyon head showing the piston and interface core locations. Cores with the same dot color present strong similarities in terms of facies association and grain-size analyses and belong to a same domain: proximal, central or distal.

Fig. 3: (A) Sparker seismic profile, CAL-083 (see location on Fig. 2) (B) Line drawing of the seismic profile. The sequence boundaries correspond to glacial/interglacial cycles defined by Rabineau et al. (2005) and Jouët et al. (this volume). Due to seismic resolution, the modern sediments are enclosed within the water/sediment strong reflector. 
Fig. 4: X-ray imaging of core samples showing the different types of facies. The image tones are in grey level. Increasing darkening is related to increasing density due to coarser particles or more consolidated material. Facies 3 materials do not allow a suitable X-ray signature. Grain size diagram shows the representative grain size curves of Facies 1, 2, 4, 5 and the muddy sand matrix part of Facies 3 (Facies 3 shell fragments are not shown but centimetric in size) . Facies 1 curve is a poorly sorted unimodal curve centered on $10 \mu \mathrm{m}$. Facies 2, 4, 5 and Facies 3 muddy sand matrix (MSM) display a bimodal curve with 5-7 $\mu \mathrm{m}$ and $250 \mu \mathrm{m}$ modes.

Fig. 5: Stratigraphic log, sedimentary facies and radioisotope measurements $\left({ }^{210} \mathrm{~Pb}_{\mathrm{exc}}\right.$ and ${ }^{137} \mathrm{Cs}$ ) of cores representative of the 3 morpho-sedimentary domains of the Bourcart canyon head. A: proximal domain; B: central domain; C: distal domain. D: close-up view of KIGC20 from the distal domain. Data show the recent deposition of sediments in the canyon head with coarse-grained particles (medium sand) blanketing the proximal domain part.

Fig. 6: Down canyon correlation within the study area of depositional units in core log transects in the axial channel (A) and on the flank (B). 3 units are defined from radioisotope measurements, X-ray description and sedimentological analyses.

Fig. 7: Detailed mean grain size data on interface cores within unit B in the study area. The grain-size curves are very similar from core to core in the central domain. Correlation with a distal domain core displays an overall decrease in mean grain-size. In the distal domain, Facies 3 directly lies on Facies 5 (Fig. 5). Distances between cores (horizontal axis) are measured along-channel.

Fig. 8: (A) Time series of current velocity, water temperature and suspended sediment concentration (SSC) recorded at the head of the Bourcart Canyon during winter 2003-2004. Light grey shaded areas indicate cold water cascading events with associated down canyon current velocities and SSC increases. Dark grey shaded area shows a "hot” water cascading events. Cascading events induce a general waxing and waning flow pattern with important internal variations. (B) Polar plot of combined current directions and velocities showing the main current directions. 
Fig. 9: Plot of current velocity (log scale) versus bottom shear stress (log scale) depending on roughness length of bed surface $(\mathrm{z} 0)$. The peak currents observed in our data gives bottom shear stress values (light grey shaded area) ranging from $0.2 \mathrm{~N} / \mathrm{m}^{2}$ to $0.53 \mathrm{~N} / \mathrm{m}^{2}$ for the different z0 values. The main body of current velocities does not exceed $0.2 \mathrm{~m} / \mathrm{s}$ corresponding to up to $0.15 \mathrm{~N} / \mathrm{m}^{2}$ bottom shear stress.

Table 1: Recognition criteria of turbidite, hyperpycnite, contourite and cascadite. Modified and complemented from (Mulder et al., 2002). This table applies to margins where continental shelf is broad (canyons are disconnected from fluvial systems during sea-level highstands). 


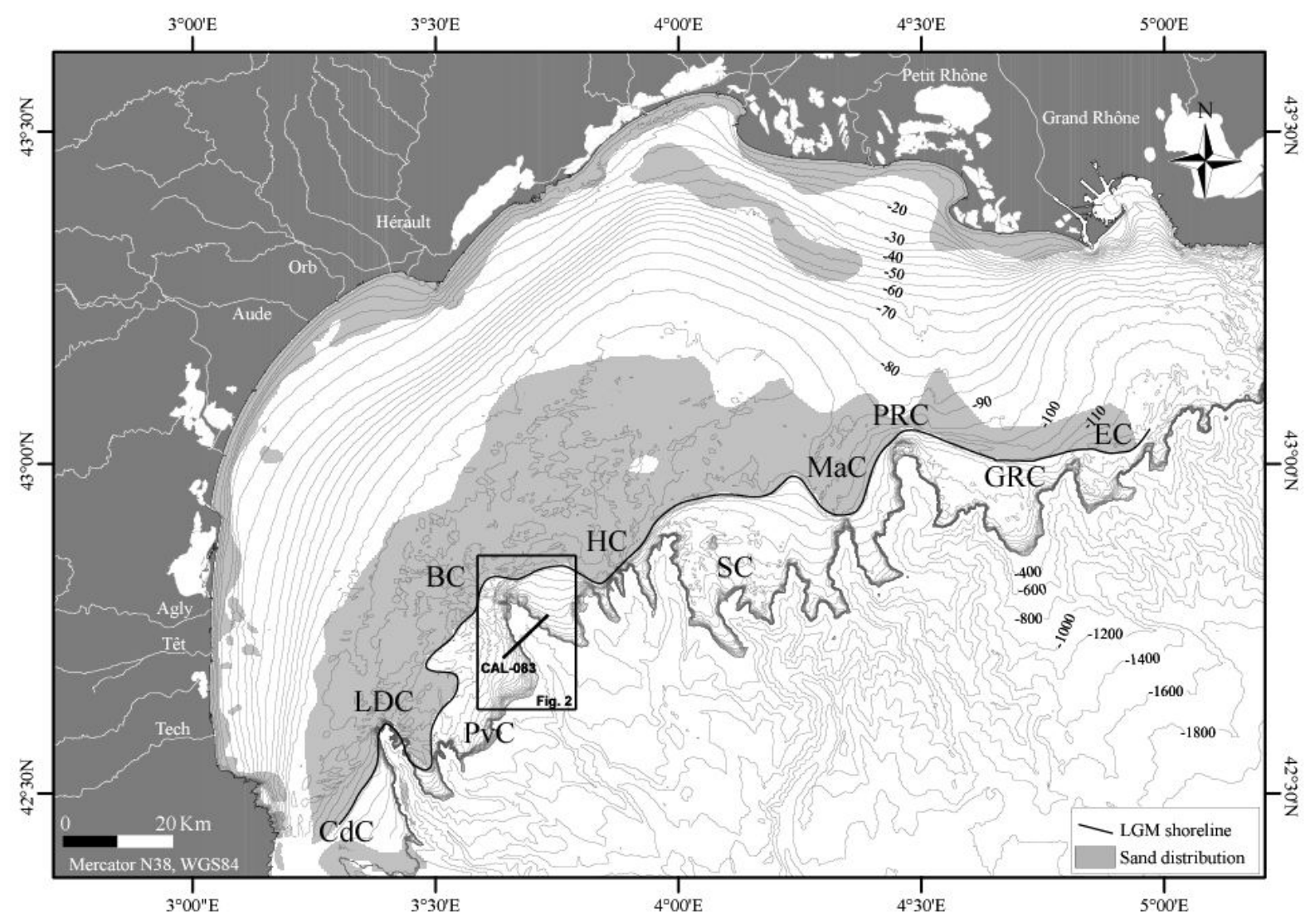

Fig. 1 


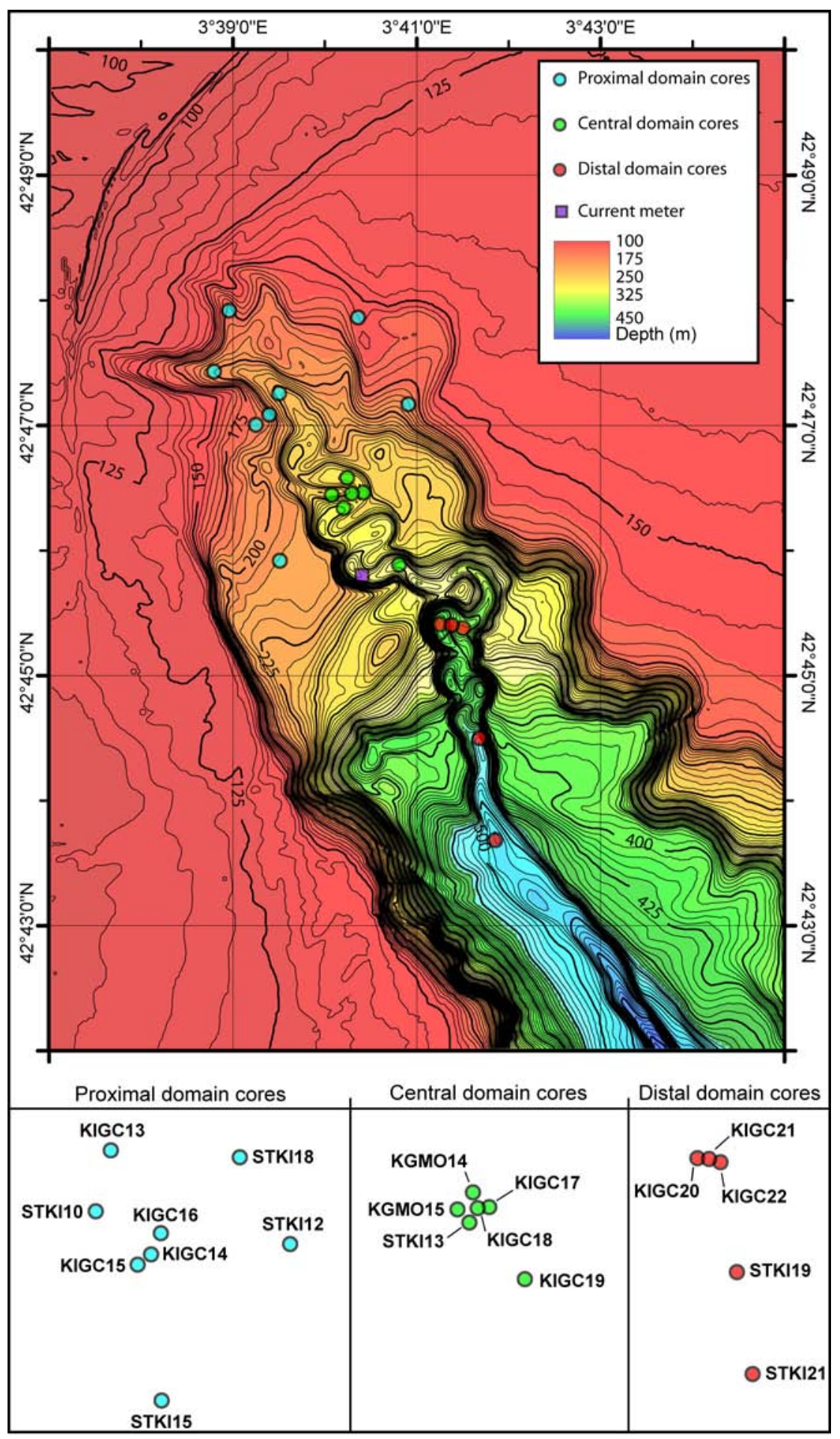

Fig. 2 


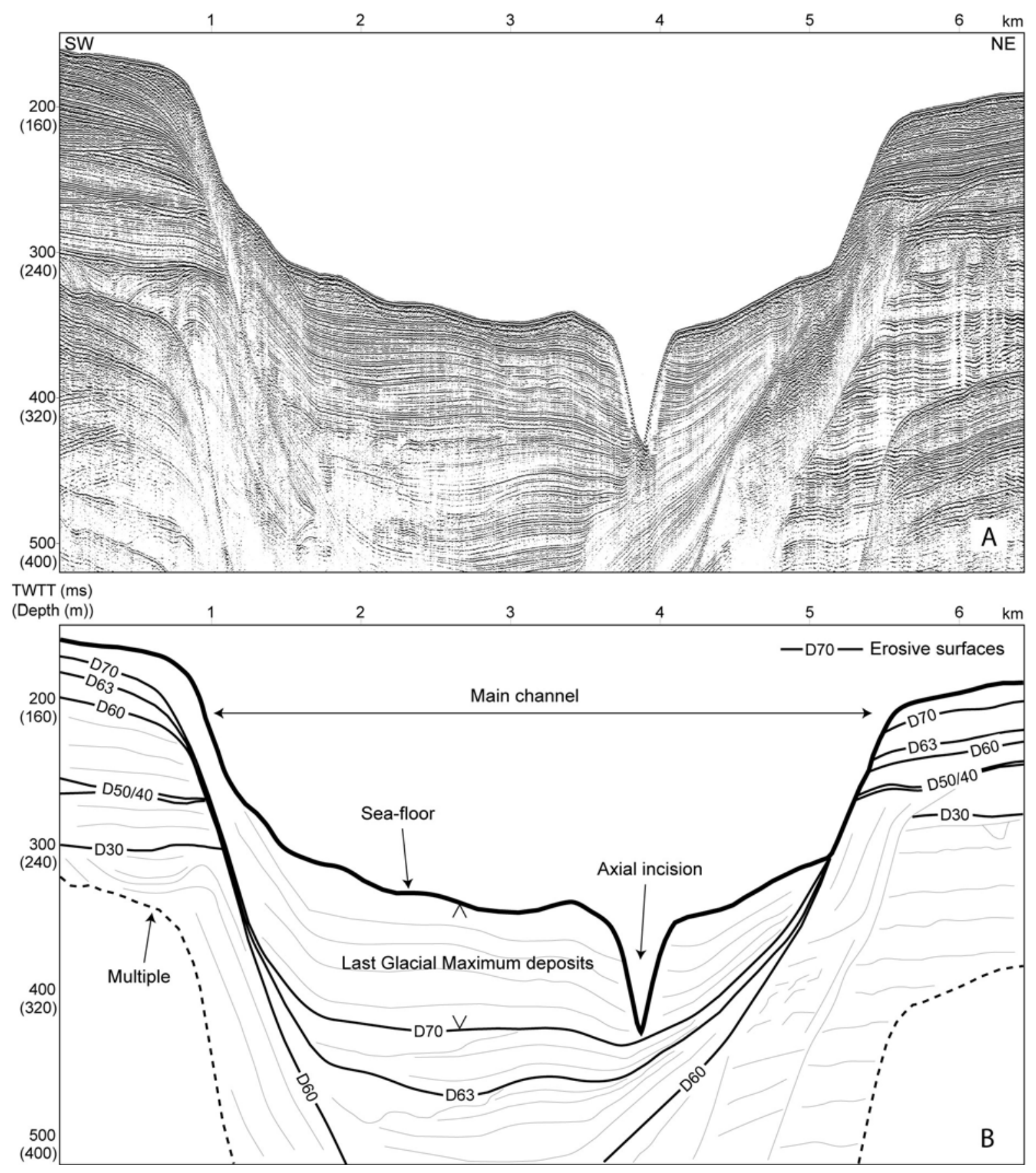

Fig. 3 

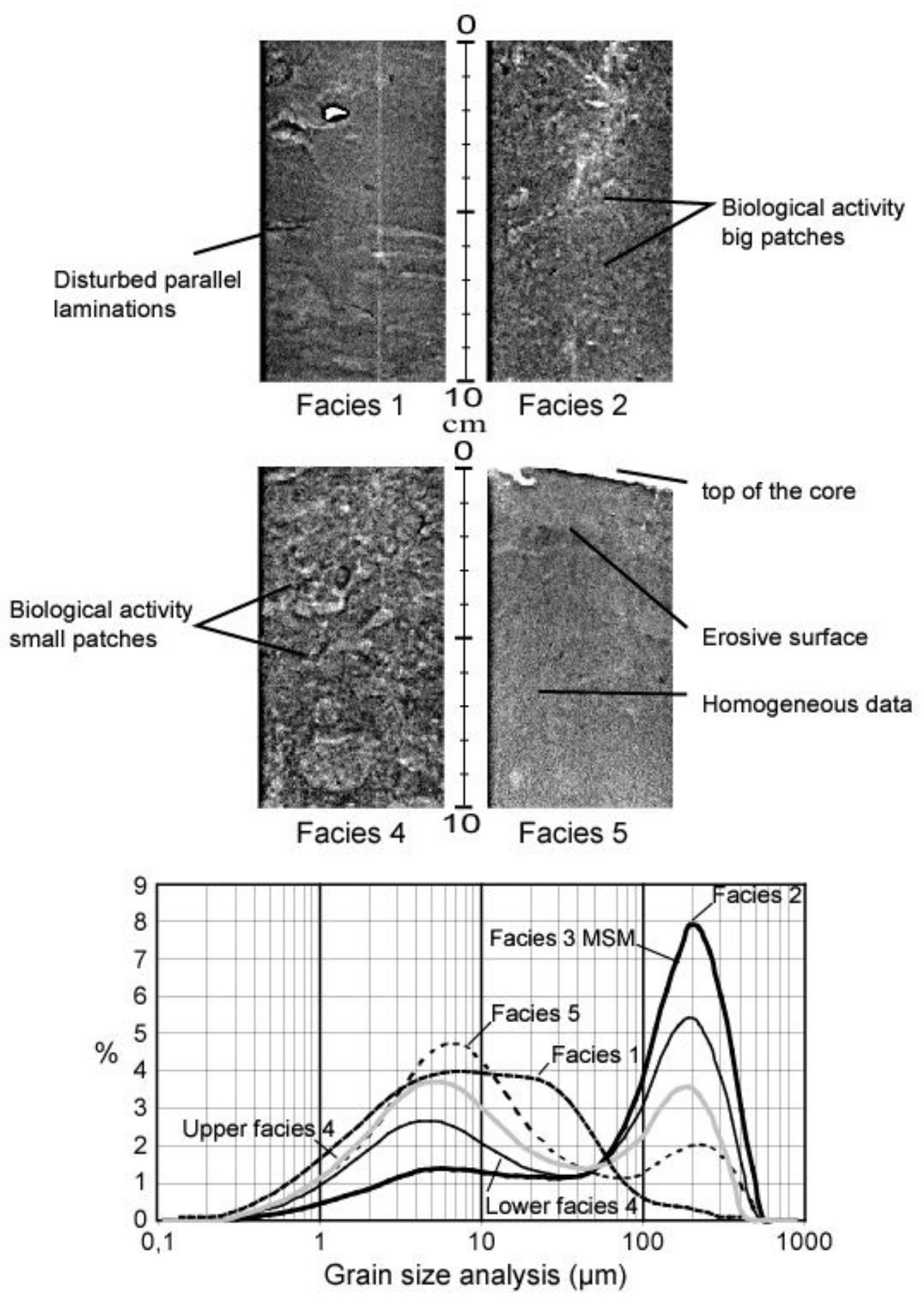

Fig. 4 

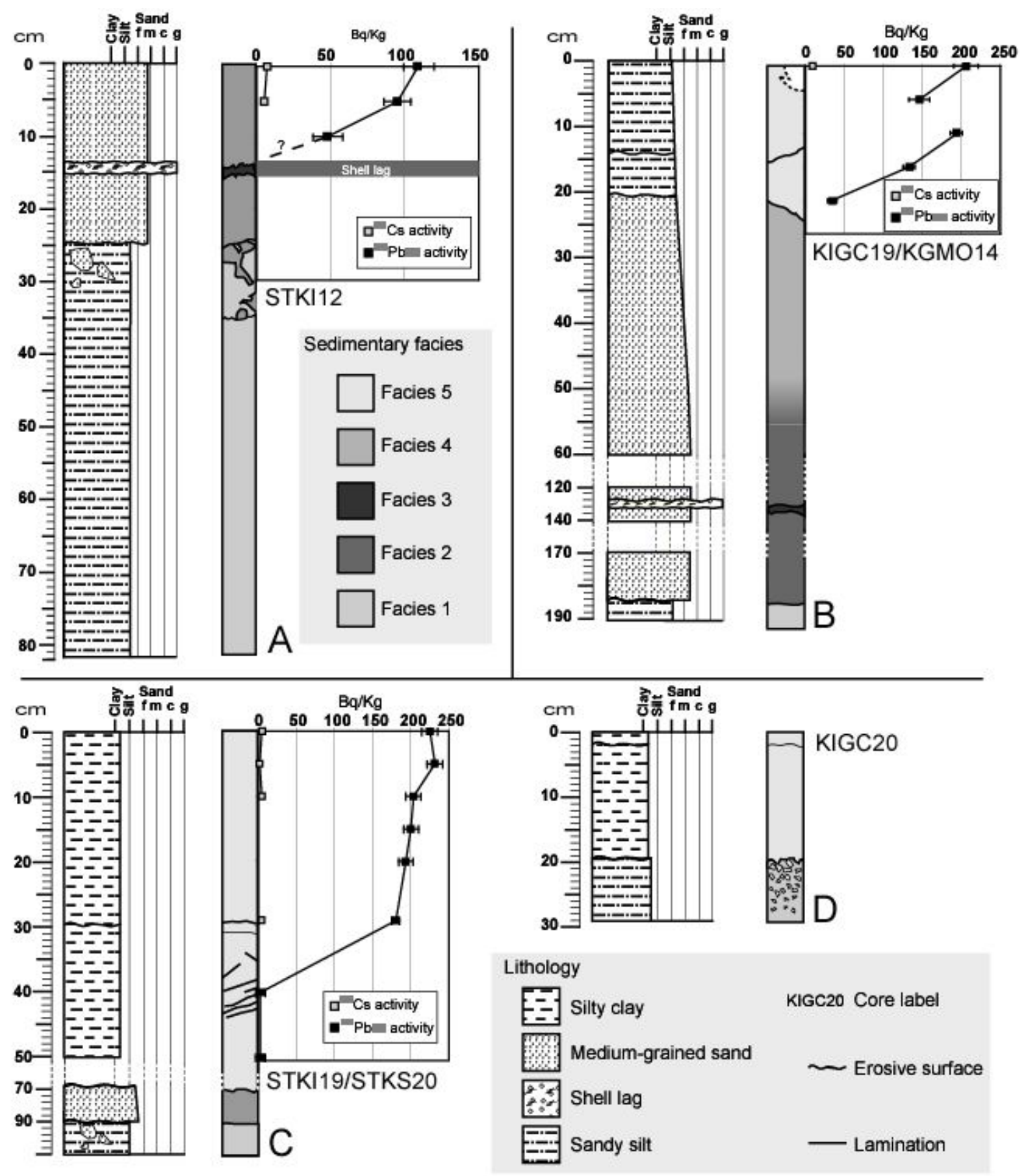

Fig. 5 

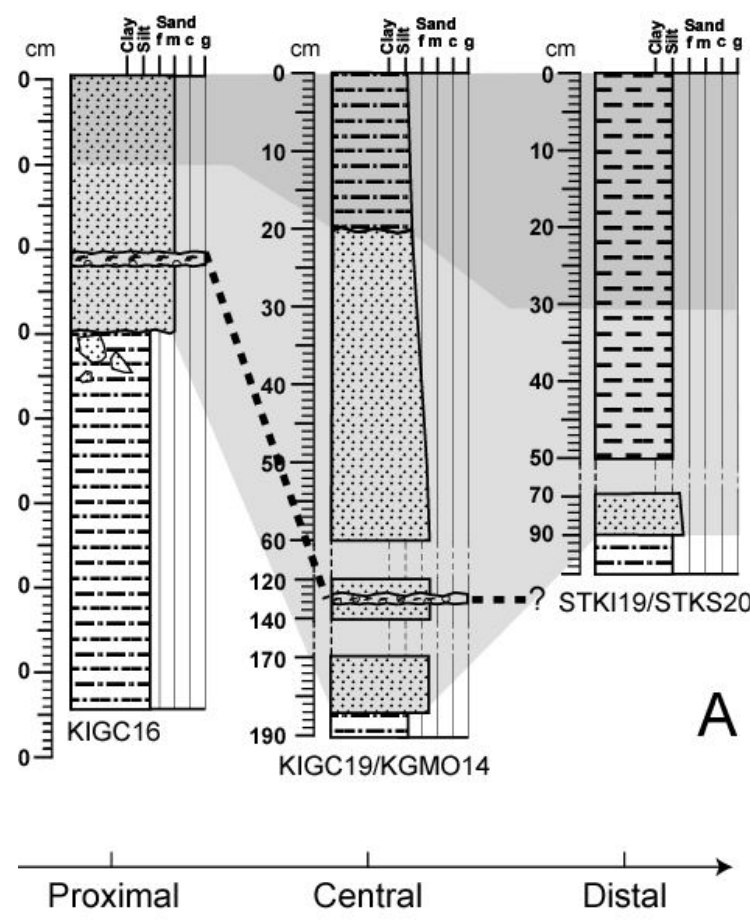
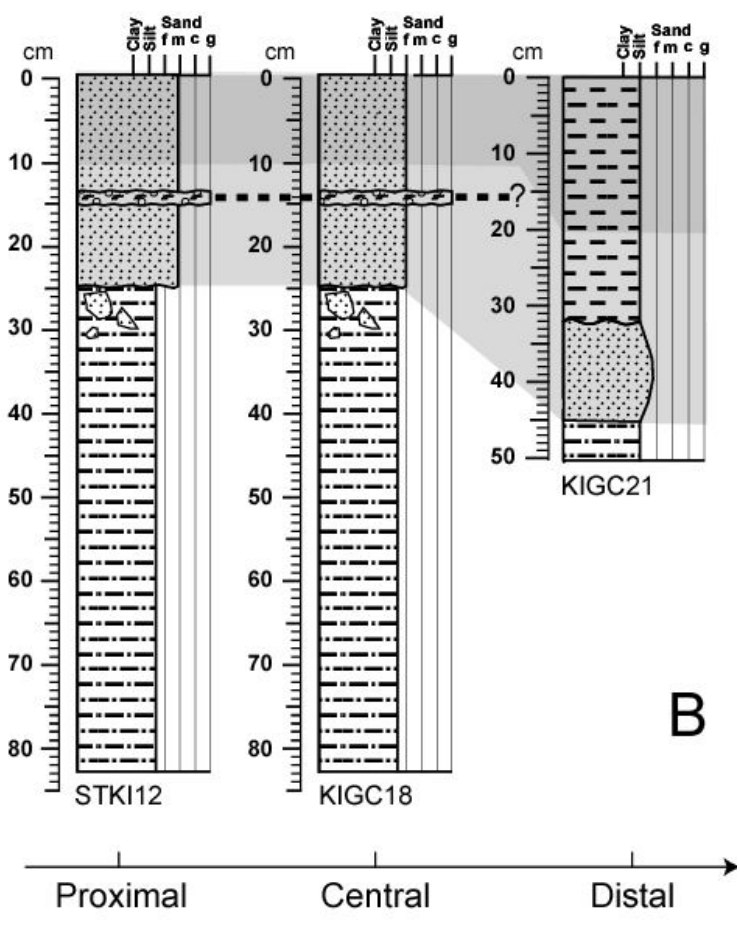

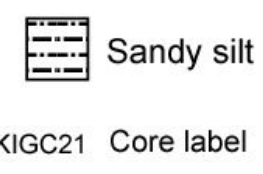

Fig. 6 


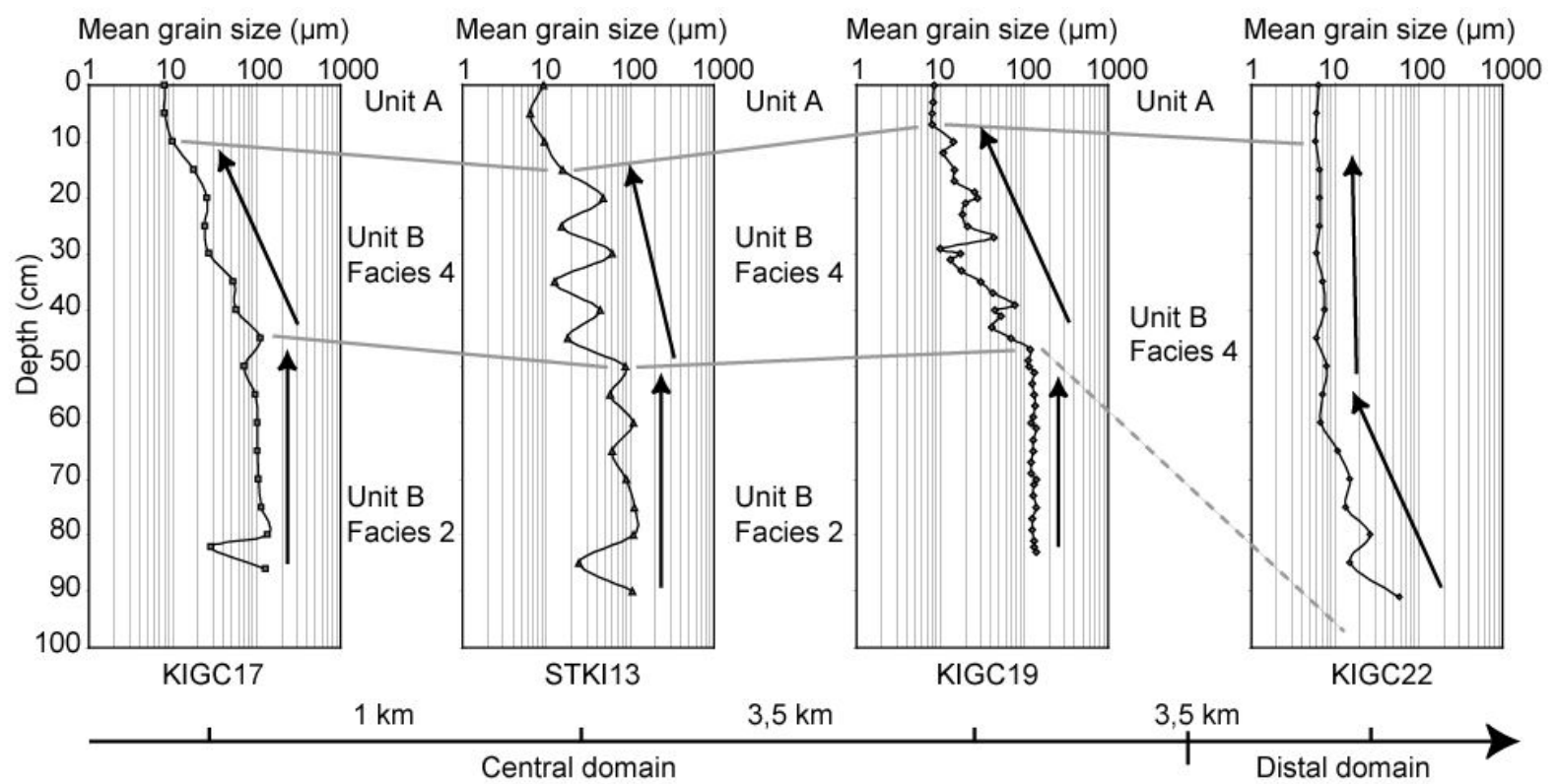

Fig. 7 


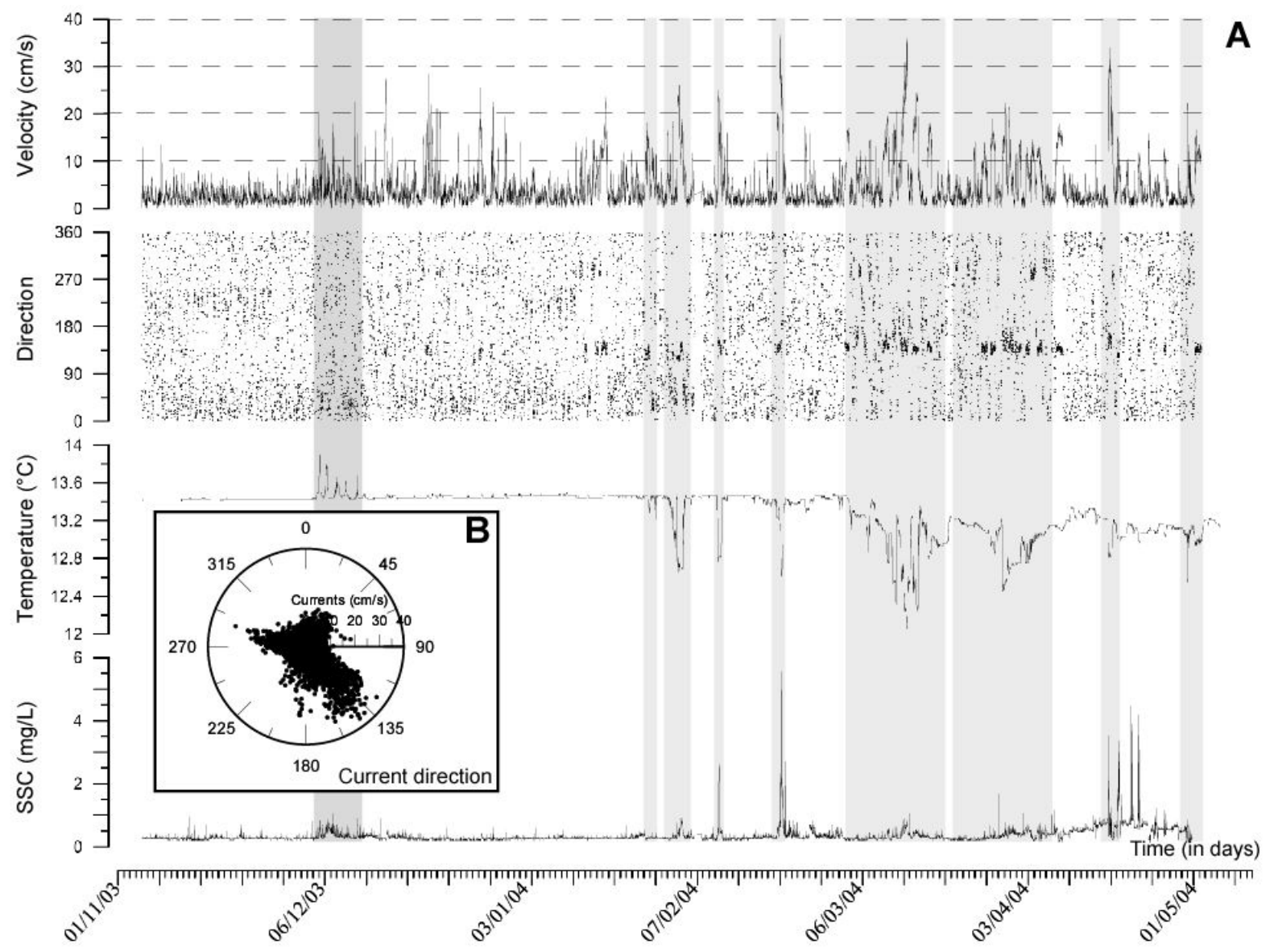

Fig. 8 


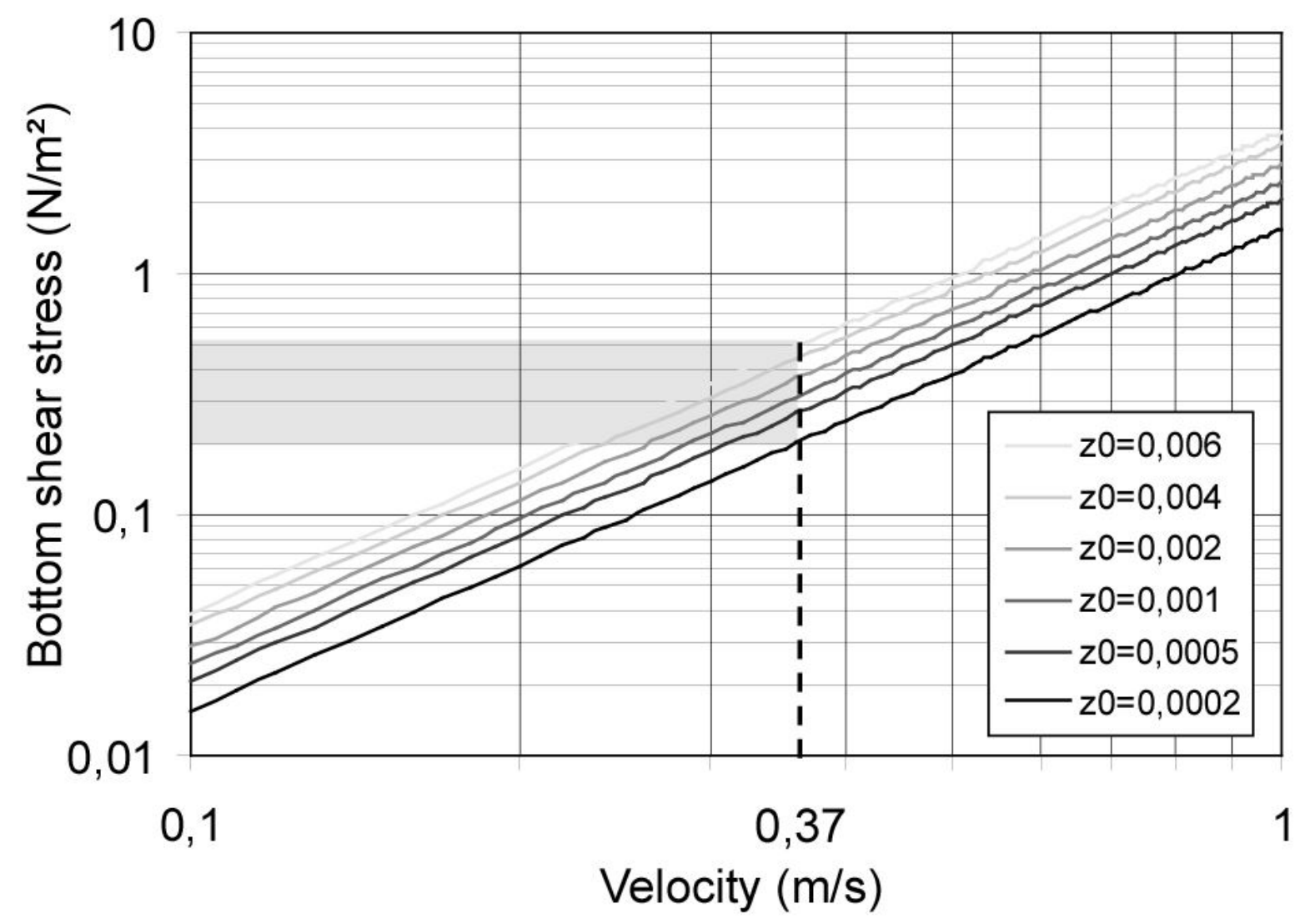

Fig. 9 


\begin{tabular}{|c|c|c|c|c|}
\hline Bed type & $\begin{array}{l}\text { Turbidite sequence } \\
\text { (Bouma like) }\end{array}$ & $\begin{array}{c}\text { Hyperpycnal turbidite sequence } \\
\text { (Hyperpycnites) }\end{array}$ & Contourite sequence & Cascadite sequence \\
\hline Flow type & Turbulent surge & Turbidity current & Contour current & $\begin{array}{l}\text { Dense water } \\
\text { cascading }\end{array}$ \\
\hline Flow behavior & $\begin{array}{l}\text { Unsteady. Mainly } \\
\text { waxing }\end{array}$ & $\begin{array}{l}\text { Mainly steady. Waxing then } \\
\text { waning }\end{array}$ & $\begin{array}{l}\text { Almost completely } \\
\text { steady. Waxing then } \\
\text { waning }\end{array}$ & $\begin{array}{l}\text { Irregular waxing } \\
\text { then irregular waning }\end{array}$ \\
\hline $\begin{array}{l}\text { Dominant flow } \\
\text { regime }\end{array}$ & Turbulent & Turbulent & Turbulent & Turbulent \\
\hline $\begin{array}{l}\text { Flow duration } \\
\text { and time for } \\
\text { deposition }\end{array}$ & Minutes to days & Hours to months & $\begin{array}{l}1000 \mathrm{~s} \text { to } 10000 \mathrm{~s} \\
\text { years }\end{array}$ & Days to weeks \\
\hline $\begin{array}{l}\text { Deposit } \\
\text { thickness }\end{array}$ & $\mathrm{mm}$ to $\mathrm{m}$ & $\mathrm{mm}$ to $\mathrm{m}$ & $\mathrm{mm}$ to $\mathrm{m}$ & Few $\mathrm{cm}$ to few $\mathrm{m}$ \\
\hline Base contact & Erosive to sharp & Gradational & Gradational & Erosive/gradational \\
\hline Top contact & Gradational & Gradational & Gradational & Gradational \\
\hline Intrabed contact & $\begin{array}{l}\text { Infrequent between } \\
\text { facies }\end{array}$ & Erosive to sharp & None & Erosive/gradational \\
\hline Grading & Clear, normal & Clear, inverse then normal & $\begin{array}{l}\text { Crude, inverse then } \\
\text { normal }\end{array}$ & $\begin{array}{l}\text { Crude inverse, then } \\
\text { clear normal }\end{array}$ \\
\hline Bioturbation & Absent to intense & Absent to intense & Intense & Intense \\
\hline Structures & $\begin{array}{l}\text { Well developed } \\
\text { parallel and cross } \\
\text { bedding, convolutes }\end{array}$ & $\begin{array}{l}\text { Well developed parallel and cross } \\
\text { bedding, Climbing frequent }\end{array}$ & $\begin{array}{l}\text { Crude and sparse } \\
\text { parallel and cross } \\
\text { bedding. Frequent } \\
\text { mottles and lenses }\end{array}$ & None \\
\hline Fauna & $\begin{array}{l}\text { Allochthonous } \\
\text { mainly marine }\end{array}$ & $\begin{array}{l}\text { Allochthonous mainly continental. } \\
\text { Frequent plant and wood fragment }\end{array}$ & Mainly autochthonous & $\begin{array}{l}\text { Mainly } \\
\text { allochthonous }\end{array}$ \\
\hline $\begin{array}{l}\text { Sea-level } \\
\text { conditions }\end{array}$ & Mainly lowstand & Mainly lowstand & Lowstand and highstand & Mainly highstand \\
\hline
\end{tabular}

Table 1 